\title{
GRAMÁTICA: O DISCURSO INDIRETO NUMA PERSPECTIVA DISCURSIVA
}

\begin{abstract}
Mariluci Bianchi
RESUMO: According Authier-Revuz, the speech functions of the reported speech are identified and analysed as one of the forms of related speech, that a the place of the Other in the through. There fore, the function of the reported speech exceed the ones defined by traditional grammar. Through the enunciations, objectify to demonstrate that the speech cited should be identify as report of enunciation acts and nor simply with words, as proclaim the traditional grammar. These insertions of speech-others presuppose a position that preside the choice: mention themselves the others for some reason, that can be in concordance, to be stand opponent the placement, for writing and/or to reinforce the position and obtain a possible effect of sense.
\end{abstract}

PALAVRAS-CHAVE: discurso indireto, gramática, locutor, receptor, enunciados, efeito de sentidos, sujeito locutor-pessoa, sujeito locutor-dados.

\section{INTRODUÇAO}

Este artigo é parte integrante da dissertação de mestrado intitulada "A legitimidade do sujeito desejante da AD e a legitimação, sob a ótica da

Mariluci Bianchi é Mestre em Letras - Estudos Lingüísticos, pelo Programa de Pós-Graduação em Letras da Universidade Federal de Santa Maria e professora no Ensino Médio e Superior. 
comunicação, de outro discurso, em meio ao discurso hegemônico da globalização", defendida em março de 2002, na UFSM. A pesquisa teve como objetivo norteador compreender o funcionamento discursivo implicado na constituição do sujeito e do sentido, no discurso cooperativista da comunicação. O corpus sobre o qual incidiu a análise foi constituído por dezoito editoriais do Jornal Hora $H$, desde sua primeira edição até a de número cento e cinqüenta e oito, abrangendo o período de 3 de setembro de 1998 a 14 de setembro de 2001.

Os recortes foram organizados em dois grupos, determinados como recorte 1 e recorte 2 , a saber: a) o primeiro diz respeito à inserção do outro por meio do discurso do sujeito locutor-pessoa (slp); b) o segundo reúne os recortes oriundos do sujeito locutor-dados (sld).

A via da Teoria do Discurso é eleita como embasamento teórico, especialmente a terceira fase da Análise de Discurso (AD3), filiada à linha de pensamento aberta por Michel Pêcheux nos anos 1960. Essa terceira fase pecheutiana é atravessada, distintamente das antecedentes, por um sujeito desejante. Pêcheux respalda Authier-Revuz, no quadro das transformações e reconfigurações da AD3.

Neste artigo, num primeiro momento, procedemos a uma sinopse das articulações e alianças entre Pêcheux e Authier-Revuz. Em seguida, discutimos os processos discursivos relacionados ao campo da enunciação, do Outro no discurso, especificamente o discurso indireto (DI), para, em seguida, analisar enunciados de recortes discursivos contemplados para o presente texto e, assim, visualizar a regularidade da marca lingüísticodiscursiva dos verbos dicendi, no fio intradiscursivo.

\section{DAS ARTICULAÇÕES E DAS ALIANÇAS}

$\mathrm{O}$ início do período de reconfiguração da $\mathrm{AD}$ está relacionado à realização do Colóquio Matérialités Discursives, realizado na Universidade de Paris X, Nanterre, em 1980. Com a finalidade de continuar e expandir as discussões suscitadas no evento, Pêcheux organiza os grupos Recherche Coopérative Programmée (RCP) e Analyse de Discours et Lecture d'Archive (ADELA). A leitura de arquivo, a discursividade e a informática são temáticas em pauta nos encontros liderados por ele até 1983, ano de seu falecimento (TEIXEIRA,1999, p. 169).

Authier-Revuz é uma das participantes do evento apresentando o trabalho Paroles tenues à distance ${ }^{1}$ (1981, p. 127-142). Aborda de forma

${ }^{1}$ Texto publicado no ano seguinte ao do Colóquio, em coletânea que reúne os trabalhos apresentados durante o evento.

254 
distinta, em relação aos procedimentos da $\mathrm{AD}$, os processos discursivos relacionados ao campo da enunciação, do outro no discurso. Esses processos são respaldados por Pêcheux, no quadro das transformações e reconfigurações da AD3.

Pêcheux e Authier-Revuz conheceram-se no CERM (Centre d'Études et de Recherches Marxistes), no final dos anos 1970. Segundo Maldidier (1990, p. 78), constituiu-se em verdadeiro encontro intelectual, pois foi marcado por ajuda mútua. Nesse sentido, vemos na bibliografia do texto por ele escrito para a DRLAC 27 (1982) a citação do texto de AuthierRevuz (1982) .

Já o artigo "A Análise de Discurso: três épocas" (1983a) apresenta a seguinte afirmação: "Alguns desenvolvimentos teóricos que abordam a questão da heterogeneidade enunciativa conduzem, ao mesmo tempo, a tematizar, nessa linha, as formas lingüístico-discursivas do discurso-outro" (p. 316). A questão sobre as heterogeneidades pressupõe uma referência a Authier-Revuz, apesar de que seu nome não esteja mencionado.

No livro Discurso: estrutura ou acontecimento (1983b) o autor cita a expressão 'heterogeneidade constitutiva' (1990, p. 51) mencionando entre parênteses que a expressão é de J. Authier. Esse mesmo procedimento está na nota 11 da página 62: "Eu me refiro aqui à noção de 'marcas de distância' que foi objeto de pesquisas recentes: cf. em particular J. Authier 'Paroles Tenues à Distance', in Matérielités Discursives"'.

Authier-Revuz elege a teoria pecheutiana como objeto de reflexão desde o início de seus estudos acadêmicos. Ela não compartilha, no entanto, com as idéias iniciais da AD (TEIXEIRA, 1999, p. 169) de entendimento do fato discursivo como sendo homogêneo; a falta de interesse quanto à superfície do discurso; e a posição do sujeito como assujeitado. Ela faz uma breve referência a Pêcheux, em seu texto de 1982 (op. cit.). Porém, é nas últimas produções pecheutianas que Authier-Revuz encontra ancoragem para apoiar-se no desenvolvimento de suas pesquisas.

Podemos verificar essa postura em sua tese (1995). Ela aponta:

(...) o apoio a esses dois exteriores que são a teoria lacaniana do sujeito e a análise de discurso no sentido de Pêcheux em seus últimos desenvolvimentos, em oposição aos exteriores antagônicos que teorizam um sujeito pleno, fonte intencional de um sentido expresso através do instrumento de comunicação ... (p. 59).

A colaboração mútua apontada por Maldidier (1990) segundo

${ }^{2} \mathrm{O}$ artigo tem como título Hétérogénéité montrée et hétérogénéite constitutive: éléments pour une approche de l'autre dans le discours. Reúne as conferências acontecidas no período de novembro de 1980 e janeiro de 1982, no seminário do DRLAV. 
Teixeira, (op. cit.) se efetiva, por um lado, à medida que Pêcheux reformula a abordagem quanto à seqüencialidade ao colocar em evidência as rupturas como possibilidades de "surpreender a presença do outro no discurso" (idem, p. 171). Por outro lado, efetiva-se em Authier-Revuz, ao eleger a noção pecheutiana de interdiscurso como elemento fundamental "para pensar os fatos relativos às não-coincidências constitutivas do discurso com ele mesmo" (idem, op. cit.).

Pêcheux ao retomar a questão da dupla heterogeneidade como não-coincidência possibilita à análise de discurso "voltar em termos novos e operacionais ao jogo do interdiscurso no intradiscurso, abrindo novas possibilidades de análise, em que, a meu ver, as formas lingüísticas têm papel bem mais destacado" (TEIXEIRA, op. cit., p. 171).

Em conseqüência dessas articulações e reconfigurações, temos o deslocamento de um sujeito-assujeitado para um efeito-sujeito que, dada sua condição desejante, permite pensar numa dupla inscrição do sujeito, primeiro como falado e num segundo momento como falante.

Enfim, é essa concepção de sujeito desejante que elegemos. Isso traz a incompletude da identificação simbólica na construção de um saber teórico novo, sendo reconhecida, à medida que optamos pela postura de viabilizarmos o diálogo que a Análise de Discurso circunscreve com outras áreas, notadamente com a Psicanálise, com a Lingüística e com a História.

A inscrição da articulação entre as abordagens de Authier-Revuz e M. Pêcheux, quanto à abordagem do sentido no discurso estando exposta ao equívoco da língua e da história, na tensão entre o dito (intradiscurso) e o já-dito (interdiscurso), possibilita-nos surpreender, na organização das seqüências discursivas, pontos de não-coincidência com o já-dito, originando uma desestruturação do efeito de evidência.

Essa heterogeneidade é distinta daquela concebida em função de formações discursivas diferentes e de sujeito em várias posições. Trata-se de uma heterogeneidade fundante, pois a homogeneidade imaginária do sujeito e de seu dizer é contraposta pelo equívoco entre estrutura e acontecimento.

Portanto, a língua e o discurso se constituem, em que o discurso ocupa um espaço teórico onde estão imbricadas as relações da língua, do sujeito, da história. Esse sujeito é definido enquanto sujeito do desejo inconsciente.

O DI: GRAMÁTICA TRADICIONAL \& PERSPECTIVA DISCURSIVA

O embasamento teórico da AD3, que elege a concepção do sujeito desejante, possibilita a intervenção da relação entre o interdiscurso e o 
intradiscurso nos procedimentos de análise em que as marcas lingüísticas, sintáticas, lexicais e enunciativas, conjuntamente, possibilitam a produção do efeito de sentido do discurso. Nessa perspectiva, o cenário das regularidades dos verbos no campo do dizer, diz respeito às marcas do discurso indireto no fio intradiscursivo pelo sujeito editorialista da comunicação (SEC).

Assim, tais marcas viabilizam a análise, pois estão "acomodadas", no discurso do $\boldsymbol{S E C}$. Quer dizer, ele seleciona o discurso do "outro" - o sujeito locutor-pessoa (slp) e o sujeito locutor-dados (sld), pelo uso dos verbos dicendi/sentiendi. Elegemos essa classificação para o conjunto de verbos recorrentes nos recortes discursivos contemplados, a partir dos estudos apresentados por Othon M. Garcia, em sua conhecida obra Comunicação em prosa moderna (1992).

De acordo com o autor, (op. cit), os verbos que, no discurso direto indicam o interlocutor e, no indireto o núcleo do predicado da oração principal, são designados de elocução ou dicendi. Esses verbos têm como função principal indicar o interlocutor que está com a palavra - esta função que nos interessa para o trabalho, e como secundária a de permitir a adjunção de orações adverbiais, normalmente reduzidas de gerúndio. $\mathrm{O}$ autor dá o seguinte exemplo para a função secundária: - Dá licença? Perguntou metendo a cabeça pela porta (M. de A., D. Casmurro, p. 373) (idem, p. 133). as semânticas:

Em relação à função principal, tais verbos pertencem a nove áre-

a) de dizer (afirmar, declarar);

b) de perguntar (indagar, interrogar);

c) de responder (retrucar, replicar);

d) de contestar (negar, objetar);

e) de concordar (assentir, anuir);

f) de exclamar (gritar, bradar);

g) pedir (solicitar, rogar);

h) exortar (animar, aconselhar);

i) ordenar (mandar, determinar), (op. cit. p. 131).

Para Garcia, os verbos dicendi, pelo menos teoricamente, devem ser transitivos ou admitir transitividade. Destaca, no entanto, que há casos em que os ficcionistas alteram a sintaxe; e também que há o emprego de muitos verbos que não são propriamente "de dizer" mas "de sentir", sendo denominados sentiendi.

O autor aponta como exemplos os verbos: gemer, suspirar, lamen$\operatorname{tar}(\mathrm{se})$, queixar-se, explodir, encavacar. Acrescenta a esses os que expres- 
sam estado de espírito, reação psicológica, emoções. E, quanto ao ponto de vista lógico-sintático, para o referido autor, os verbos sentiendi supõem a existência de um legítimo dicendi oculto e anteposto à fala, e posposto caso o sentiendi seja flexionado para o gerúndio.

De acordo com Garcia (idem), numa perspectiva ligada à gramática tradicional, o discurso direto (DD) e o discurso indireto (DI) são técnicas de diálogo. Caracteriza o narrador do DD, como sendo fiel na reprodução da fala das personagens. E, quanto ao narrador do DI, caracteriza a ocorrência da incorporação do narrador na sua linguagem, da fala das personagens, transmitindo aos leitores a essência do pensamento a elas atribuído.

A função do DI na perspectiva discursiva extrapola as definidas pela gramática tradicional. Segundo Authier-Revuz (1978), as funções discursivas do DI são identificadas e analisadas como uma das formas do discurso relatado que marca o lugar do outro no discurso. O DI funciona como mecanismo de relação entre o discurso e o outro.

Authier-Revuz inicia suas publicações acadêmicas no final dos anos 1970."Les formes du duscours rapporté"(1978) é um artigo em que a autora já apresenta questões sobre as rupturas enunciativas, de que ela aprofundará em suas pesquisas posteriores. Nesse artigo, aponta que o discurso citado deve ser identificado como relato de atos de enunciação e não simplesmente de palavras.

Ainda em relação ao artigo (op. cit.), Authier-Revuz apresenta várias teorias de autores que investigaram o tema, optando pelo caminho que identifica o discurso direto (DD) e o discurso indireto (DI) como sendo modos distintos de relatar a palavra do outro. Uma vez que elegemos o DI, dentre as diversas formas do sujeito manifestar-se em relação ao fenômeno do discurso citado, é disso que passamos a tratar, especificamente, com o respaldo da autora em evidência

A idéia da existência de dois locutores no DI, (op. cit.) não deve pressupor a sua ambigüidade. Essa relação entre o DI e a palavra relatada, no entanto, deve ser entendida como um discurso de um locutor $\boldsymbol{L}$ para um receptor $\boldsymbol{R}$ sobre a palavra de um outro locutor $\boldsymbol{l}$ a um outro receptor $\boldsymbol{r}$. Entre a parte de $\boldsymbol{L}$ e de $\boldsymbol{l}$ a ocorrência da linha divisória é apenas imaginária.

A irredutibilidade do DI ao DD é representada, com a utilização do verbo "dizer", assim: dizer \{: “...” para o DD; dizer \{que ... para o DI. Em relação ao que presente no DI, Authier-Revuz critica a classificação dada pela gramática tradicional como marcador da variação morfossintática do DD.

A autora retoma e aprofunda estas questões em Palavras incertas: as não coincidências do dizer (1998). Enfatiza, inicialmente, que a abordagem da gramática tradicional em relação ao campo do discurso relatado é limitada a três formas: discurso direto (DD), discurso indireto (DI) e o indireto livre (DIL). 
O DD é tido como de funcionamento simples no plano sintático e fiel e objetivo no plano semântico-enunciativo; o DI é caracterizado como uma variante morfossintática, derivável a partir do DD por regras de transformação das pessoas e dos tempos; e finalmente o DIL é tido como uma mistura de DI e DD, que suprime o termo subordinante, sendo típico em textos literários.

Por um prisma da autora em foco, as afirmações da gramática tradicional, em relação ao discurso relatado são inadequadas, parciais e empobrecedoras (p. 134- 35). Segundo ela, o DD não é nem objetivo e nem fiel, pois a reprodução da materialidade exata de um enunciado não significa restituir o ato de enunciação. Esse procedimento Authier-Revuz classifica-o de não adequado.

Em relação ao DI, aponta que ele deriva de um processo de uma operação diferenciada da alteração morfossintática do DD, como apregoa a gramática tradicional. O DI na perspectiva da autora é como um "operador de tradução", que nada explica sobre o significante do enunciado que ele relata, mas apenas sobre o significado. Assim, se no DD ocorre uma operação de citação de uma mensagem do ato relatado, no DI há uma re (utilização) do discurso outro.

A característica de parcialidade inscrita pela autora, deve-se ao fato de que a gramática tradicional comporta apenas o DD, DI e DIL. Ela aponta outras formas de representação do discurso outro no discurso, tais como o discurso direto livre (DDL): Estou com fome, vou pedir um lanche; e da modalização do discurso em discurso segundo: "segundo x...".

Authier-Revuz (1998, p. 143) propõe dois modos, mediante os quais a análise deve destacar a oposição. São eles:

- modos explícitos, unívocos de representação de um discurso outro, marcados com a ajuda de formas da língua, ou sejam aquelas inventariáveis em uma gramática e

- modos não marcados na língua, nem unívocos, nem inventariáveis, mas derivando de uma interpretação que leva em conta o contexto linear e/ ou situacional (quem fala? para quem ... etc). Adaptando à perspectiva discursiva, a interpretação leva em conta o acontecimento discursivo, abordado como o encontro entre uma memória e um acontecimento.

Ainda em relação à análise, a autora aponta níveis para o seu desenvolvimento. São eles:

1. das formas marcadas, unívocas, tais como, o DD, DI, modalização em discurso segundo, sobre o conteúdo e modalização em discurso segundo, sobre as palavras; 
2.das formas marcadas que exigem um trabalho interpretativo, como, por exemplo, as aspas e itálicos;

3. das formas puramente interpretativas, as quais correspondem ao DDL, DIL e as citações escondidas, as alusões e as reminiscências.

Apesar de reconhecer a língua como ordem própria, Authier-Revuz recorre à Psicanálise, sob a leitura lacaniana de Freud, ao dialogismo de M. Bakhtin e ao conceito pecheutiano de interdiscurso para traçar a heterogeneidade constitutiva do sujeito e de seu dizer.

O DI COMO MECANISMO DE RELAÇAO ENTRE O DISCURSO EO OUTRO

Em nossa análise, aliando-nos a Authier-Revuz, optamos pelo modo que considera o acontecimento discursivo como o encontro entre uma memória e um acontecimento. E, dentre os níveis, o das formas marcadas, mais especificamente o DI.

Assim em: (Ed. 2) Por mais que o presidente da República, acompanhado da grande imprensa, diga que o país está no rumo certo, não há como negar que a política econômica atual está gerando uma profunda crise social, talvez a maior de toda a nossa história (E4) atentamos para o 'como' o discurso cooperativista da comunicação é legitimado pelo sujeito editorialista da comunicação (SEC) no Jornal Hora H, no plano lingüísticodiscursivo pela marca dos verbos dicendi.

Atentamos também como esse sujeito vai constituindo relações, tendo a globalização como acontecimento, "isto é, descrições de situações, de sintomas e de atos (a efetuar ou evitar) associados às ameaças multiformes de um real do qual 'ninguém pode ignorar a lei' - porque esse real é impiedoso" (PÊCHEUX, 1997e, pp. 34-5).

Os recortes que constituem o corpus estão relacionados à idéia de interdiscurso enquanto pré-construído e enquanto discurso transverso. Entendemos o pré-construído como produto de enunciações anteriores, provocando um efeito de evidência, que é surpreendido na organização das seqüências discursivas. Assim, surgem pontos de não-coincidência com o já-dito (interdiscurso) no dito (intradiscurso), ocasionando o rompimento da suposta homogeneidade do simbólico.

Então, o discurso do sujeito editorialista da comunicação (SEC), veiculado pelo Jornal Hora H, em contraposição ao discurso da globalização é uma constante. É a partir desse discurso que o sujeito do discurso cooperativista se manifesta. A máxima Qualquer país fora da globalização estará fadado à desgraça e à destruição assume, portanto, a 
posição de já-dito, de memória discursiva, (interdiscurso) disfarçada no intradiscurso, como discurso transverso.

Os sentidos migratórios é que fundam o discurso transverso, que no caso desta pesquisa, é o discurso jornalístico dissociado da indústria cultural globalizada - o discurso do Jornal Hora H. Recorremos à teoria pecheutiana quanto à noção de que o interdiscurso enquanto discurso transverso "atravessa e põe em conexão entre si os elementos discursivos constituídos pelo interdiscurso enquanto pré-construído, que fornece, por assim dizer, a matéria-prima na qual o sujeito se constitui como 'sujeito falante"” (PÊCHEUX, 1997b, p. 167).

Portanto, a constituição do sujeito falante está presente nos recortes discursivos contemplados, que constituem o corpus discursivo, e possibilitam visualizar a regularidade da marca lingüístico-discursiva dos verbos dicendi, no fio intradiscursivo. Esses verbos denotam a tomada de posição que leva "um grupo de cidadãos e cidadãs, institucionalmente organizados" a partir do fenômeno relacionado à globalização, a uma escolha.

Esse movimento entre discursos no interior do próprio discurso ocorre, no entendimento de Authier-Revuz (1999, p. 10), uma vez que "a lei de todo discurso é de fazer-se, inevitavelmente, no meio do já dito dos outros discursos". Podemos verificar como tais efeitos de sentidos estão presentes nos enunciados destacados:

\section{R 1- Enunciado 10 -}

É neste contexto que se pode afirmar que o segundo governo Fernando Henrique vive a sua fase terminal. Os fatos políticos da semana afirmam exatamente isso. ACM está atuando em faixa própria há muito tempo. Os caciques tucanos, através do vice-presidente da Executiva nacional do partido, Mendonça de Barros, dizem que é preciso assumir a 'derrota parcial do real'. (Ed. 10)

R1- Enunciado 16-

A polêmica que envolve a fixação do novo valor do salário mínimo precisa ser analisada detidamente. Não há nenhuma novidade em que os deputados da oposição e os sindicalistas estejam propondo um aumento maior do que o proposto pelo poder executivo. Esse ato repete-se todos os anos. A novidade é a posição do senador Antônio Carlos Magalhães e do PFL que defendem um valor de 100 dólares para o salário mínimo. Cabe lembrar que o presidente do Congresso já fez críticas ao excesso de ingerência do FMI na economia nacional e denunciou a pobreza crônica que atinge parcelas importantes da sociedade brasileira. (Ed. 15)

Nos enunciados acima, $\boldsymbol{L}$ (SEC), por meio do DI marca a presença do discurso-outro que é oriundo, justamente do discurso da globalização $(\boldsymbol{D G})$, e a sua inserção pelo $\boldsymbol{L}(\boldsymbol{S E C})$ serve para desqualificá-lo e ironizá-lo e assim reforçar o seu ponto de vista. 
Essa desqualificação que $\boldsymbol{L}$ (SEC) quer legitimar ocorre pela inclusão do discurso $\boldsymbol{D G}$, representado, no enunciado 10 (R1), por meio de uma "autoridade" desse discurso - o vice-presidente da executiva nacional do partido dominante no cenário político do Brasil, Mendonça de Barros, propositadamente inserido no fio do discurso enunciando que é preciso assumir "a derrota parcial do real". Temos como efeito de sentido que a estabilidade e o controle da inflação foram metas anunciadas pelos neoliberais, porém não atingidas.

Já, o outro discurso $\boldsymbol{D} \boldsymbol{G}$ inserido, ironicamente, por $\boldsymbol{L}$ (SEC) e representado no enunciado 16 (R1) é do senador Antônio Carlos Magalhães, que denuncia a ingerência do FMI e a pobreza do povo brasileiro. Neste caso, temos implícito que o progresso anunciado pelos neoliberais (e o senador é um dos seus principais representantes na política brasileira) é um mito, pois a concentração sem precedentes da renda e as crises financeiras são conseqüências desse sistema.

Portanto, ao inserir o discurso de advertência de Antônio Carlos Magalhães ao $\boldsymbol{D} \boldsymbol{G}$, ou seja, ao discurso que ele próprio representa, o $\boldsymbol{L}$ (SEC) está desqualificando ambos, isto é, o sujeito Antônio Carlos Magalhães e o seu discurso e com isso $\boldsymbol{L}$ (SEC) sustenta o seu ponto de vista e garante a sua posição de sujeito.

O discurso-outro, quer seja o slp ou o sld, aparece para mostrar que o SEC dele se afasta e/ou se alia para legitimar o seu discurso. Essa legitimação do discurso do SEC constitui-se em ruptura de sentido em relação à máxima de que "Qualquer país fora da globalização estará fadado à desgraça e à destruição", veiculando um discurso jornalístico, que representa alteração e oposição à globalização que ocorre no final do século XX e no limiar do século XXI.

\section{ALGUMAS CONSIDERAÇÕES FINAIS}

A Análise de Discurso filiada à linha de pensamento aberta por Michel Pêcheux, nos anos 1960, se propôs a refletir sobre a linguagem, o mundo e a busca da verdade na prática científica. Ela pressupõe a linguagem não transparente e a questão colocada é: como este texto significa? Assim, a interpretação tem origem no próprio texto, que é concebido em sua discursividade, possuidor de materialidade simbólica própria significativa.

Certamente, um estudo crítico pressupõe que o entendimento do processo de construção de sentidos não se resolve somente através de uma análise do tipo de gramática textual, mas por uma leitura que entre na teia da produção dos sentidos para perceber de que forma o discurso se consti- 
tui. Temos consciência que uma leitura crítica se efetiva como uma interpretação dentre outras, trazendo à tona a idéia de incompletude, a possibilidade de novas leituras que, por sua vez, mobilizam novos sentidos.

Tendo em vista a análise efetivada, constatamos que o $\boldsymbol{S E C}$ opta por verbos dicendi ao manifestar-se sobre a globalização. Ele apresenta-se como um tradutor, que faz uso de suas palavras para remeter a um outro como fonte do sentido que relata, que no caso desse estudo, diz respeito ao sujeito locutor-pessoa (slp), ao sujeito locutor-dados ( $\mathbf{s l d})$.

Distintamente das concepções presentes na gramática tradicional, de que o DI é uma variante morfossintática, derivável a partir do discurso direto (DD) por regras de transformação das pessoas e dos tempos, as análises possibilitaram-nos constatar que o DI pode ser caracterizado como um 'operador de tradução', que nada explica sobre o significante do enunciado que ele relata, mas apenas sobre o significado. Portanto, no DD ocorre uma operação de citação de uma mensagem do ato relatado; já no DI, há uma re (utilização) do discurso Outro.

Dessa forma, em relação aos enunciados evidenciados, verificouse que o $\boldsymbol{L}(\boldsymbol{S} E \boldsymbol{C})$ ao citar outros locutores $\boldsymbol{l}$ está estabelecendo interlocução. No entanto, pode-se observar, em relação à participação do $\boldsymbol{L}(\boldsymbol{S E C})$, que a neutralidade diante do que é dito, ao fazer uso do recurso do DI, é aparente, pois ao integrar as palavras do outro no seu discurso está, estrategicamente, emitindo julgamentos. $\mathrm{O} \boldsymbol{L}$ (SEC) transfere o discurso a $\boldsymbol{l}$ para manifestar, na realidade, o seu ponto de vista.

\section{BIBLIOGRAFIA}

AUTHIER-REVUZ, J. Lés formes du discours rapporté. D.R.L.A.V., Université de Paris VIII, n. 17, p. 1-88, 1978.

. Paroles tenues à distance. In: CONEIN et. al. Matérialités discursives. Lille, Presses universitaires de Lille, 1981. p. 17-142.

. Hétérogénéité montrée et hétérogénéité constitutive : éléments pour une approche de l' autre dans lé discours. D.R.L.A.V, Paris, Ccentre de recherches de L'Université de Paris VII, n. 26, p. 91-151, 1982.

. Ces mots qui ne vont pás de soi: Boucles réflexives et non-coincidences du dire. Paris, Larousse, 1995.

. Palavras incertas: as não-coincidências do dizer. Campinas, SP, UNICAMP, 1998. 
. Dialogismo e Divulgação Científica. In: Rua, Campinas, Unicamp, n. 5, p. 9- 15, 1999.

GARCIA, O. M. Comunicação em prosa moderna. 15 ed. Rio de Janeiro, Ed. da Fundação Getúlio Vargas, 1992.

MALDIDER, D. L'inquiétude du discours.. Paris, Cendres, 1990.

PÊCHEUX, M. (1983).A análise de discurso: três épocas. In: GADET, F.\& HAK, T. (org.) Por uma análise automática do discurso: uma introdução à obra de Michel Pêcheux. 2 ed. Campinas, UNICAMP, 1993. . Sur la (dé-) construction des théories linguistiques. D.R.L.A.V, n. 27, p. 1-24, 1982.

O discurso: estrutura ou acontecimento. 2 ed. Campinas, Pontes, 1997.

TEIXEIRA, T. M. L. A presença do outro no um: um exercício de análise em canções de Chico Buarque. Tese de Doutorado. Porto Alegre, RS, PUC-RS, 1999.

\section{REFERÊNCIAS DOS EDITORIAIS CITADOS}

EDITORIAL 2. De como resistir para uma sociedade melhor. In: Hora H, Ijuí, RS, p. 2, 31 de dez. 1998 a 08 de jan. de 1999.

EDITORIAL 10. O novo discurso da base governista. In: Hora H, Ijuí, RS, p.2, 08 a 14 de out. de 1999

EDITORIAL 15. O movimento dos estudantes e a crise social. In: Hora H, Ijuí, RS, p. 2, 04 a 10 de fev. de 2000. 